\title{
The retirement crisis of South African Dutch Reformed ministers: An empirical study
}

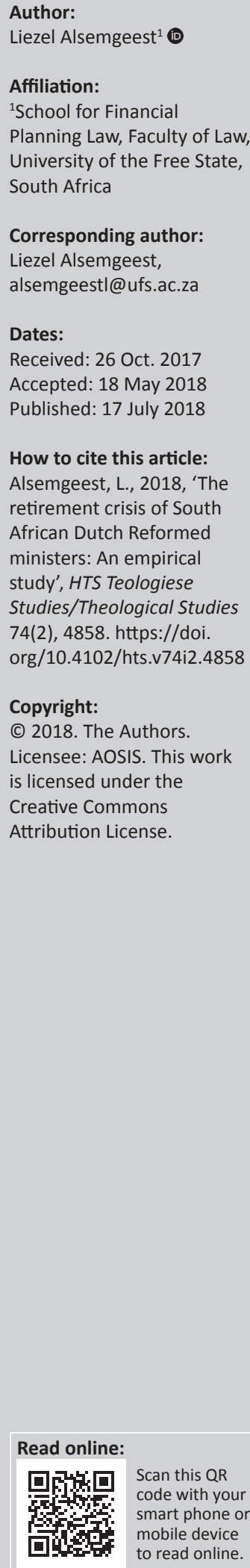

There has been a backlash from recently graduated proponents of the Dutch Reformed Church of South Africa that they are unemployed not just because of dwindling church member numbers, but mainly because contract posts are being filled by retired ministers and not by the proponents. International research suggests that the reason retired ministers continue working is not necessarily because they want to, but because they do not have sufficient retirement savings. The aim of this study was to examine the perceptions of Dutch Reformed ministers who would reach retirement age within the next 5 years, in an effort to establish their preparedness for retirement. The respondents were sent a link to an online questionnaire and 147 useable questionnaires were returned, representing a response rate of $47.7 \%$. The results indicated that almost half of the respondents stated that they would want to continue working in a part-time ministerial post after retirement and that the ministers' motivation to continue working was directly linked to their lack of financial provision for retirement. A major cause for concern is the high number of respondents who selected the 'uncertain' response option for most of the retirement questions, as they are so close to retirement. An intervention to incorporate financial management specifically in theological training is urgently needed.

\section{Introduction}

According to recent estimates, more than $55 \%$ of the current full-time Dutch Reformed ministry corps fall between the ages of 51 and 65 and will have to retire within the next 15 years (Agenda Algemene Sinode 2015). South Africans are considered to be among the worst savers in the world (Grobler 2016). The majority of South Africans do not have the luxury of having excess funds that can go towards savings and it has been estimated that more than $40 \%$ only start saving towards retirement between the ages of 45 and 50 (Geldenhuys 2010). According to the South African National Treasury, only $6 \%$ of South Africans retire comfortably and maintain their current lifestyle after retirement (National Treasury 2014). As a result of low or no savings, approximately 31\% of South Africans have to continue working after they have reached retirement age (Geldenhuys 2010).

An article that appeared in Kerkbode on 18 May 2012, which reported that the majority of recently graduated proponents of the Dutch Reformed Church were unemployed (Kerkbode 2012:1), evoked wide and strong responses. The article and subsequent feedback from social media revealed intense reactions from both the older and younger readership of the magazine, specifically concerning the possible reasons behind this phenomenon (Facebook 2012).

According to the Kerkbode article, the main reason for the unemployment of recently graduated proponents and young ministers was the economic downturn, which forced older ministers to continue working and caught the church off guard (Kerkbode 2012:1). In addition, the numbers of church members have diminished sharply since the start of the 21st century in traditional Afrikaans-speaking Reformed churches in South Africa (Schoeman 2014). There have been myriad reasons put forth for this phenomenon, of which depopulation, urbanisation, declining church attendance and a decline in birth rates are just a few measurable explanations that have been offered (De Klerk \& Van Helden 2011).

The economic slump, together with declining numbers of church members, has resulted in the closure of churches or the merging of congregations in an effort to survive (Schoeman 2014). Contract posts with a limited term were created in response to a temporary oversupply of graduated proponents, in an effort to assist them in finding a more permanent placement. However, the majority of these contract posts are now filled by older ministers between the ages

Note: This article is published in the section Practical Theology of the Society for Practical Theology in South Africa. 
of 60 and 70 years, which is contrary to the initial motivation behind the creation of these contract posts (Kerkbode 2012:1).

The purpose of this study was to empirically test the outlook of ministers close to retirement, in an effort to establish their preparedness for retirement - from a financial perspective. The article is structured to provide an overview of retirement and savings in South Africa, as well as a review of international research that focused on clergy and retirement. The data were collected by distributing questionnaires among Dutch Reformed ministers who planned to retire within the next 5 years. The conclusion and potential implications follow the discussion of the findings.

\section{Retirement and savings in South Africa}

According to the World Health Organization (WHO 2015), global life expectancy increased by an average of 5 years between 2000 and 2015 and this was the fastest increase since the 1960s. In 2015 the average global life expectancy was 71.4 years. The main reason for this increase is enhanced healthcare (Geldenhuys 2010).

In South Africa the average life expectancy is much lower at approximately 50 years of age, but because of the vastly different socio-economic groupings in South Africa there are various factors that have to be taken into account in order to determine a person's life expectancy (Palmer \& Krige 2013). The determination of life expectancy is extremely important, as it has a direct impact on retirement funds (Izekenova et al. 2015).

In a study conducted by Palmer and Krige (2013), they calculated the possible life expectancy of three fictitious people in an effort to indicate how life expectancy can be predicted based on the following factors:

- Living Standards Measure (LSM) grouping

- HIV prevalence

- ethnic background

- weight

- exercise

- family illness

- stress

- substance abuse

- diet.

The three fictitious people were Person_X, a white male living in the Western Cape, Person_Y, a black female living in Limpopo, and Person_Z, an Indian male living in Johannesburg. Person_X's description was provided as follows:

The first individual, named Person_X, is a white male living in the Western Cape. Degree educated, this person resides in the LSM 10 group, and has private medical aid and a large portion of disposable income. No AIDS test has been taken. Person_X is health conscious, he exercises regularly, eats healthily and is carrying no extra weight. There is a small history of illness in the family, prostate cancer and minor heart disease. Staying away from the corporate world, stress is kept to a minimum, and he doesn't smoke. (Palmer \& Krige 2013:163)

The population that took part in this study is the closest in demographic features and lifestyle to Person_X than either of the other two options provided. In the study, the adjusted life expectancy of Person_Y was found to be 72 years of age (black female living in Limpopo), while Person_Z's was found to be only 67 years (Indian male living in Johannesburg). Person_X's life expectancy was calculated to be approximately 87 years of age, which is much higher than the average South African life expectancy of 50, as well as the global life expectancy of 71 (Palmer \& Krige 2013). Therefore, it can be assumed that on average the population in this study will live well beyond 80 years of age, which has a great impact on retirement and retirement funds, in particular.

According to the 2017 Old Mutual Retirement Monitor, the South African retirement situation looks quite dire. From their survey they found that only $70 \%$ of their working respondents belonged to a retirement fund. Also, it was found that of the respondents who did not have a retirement fund, 58\% would have to continue working in order to survive (Old Mutual 2017).

As mentioned before, only an estimated $6 \%$ of South Africans can retire comfortably and maintain the same level of lifestyle that they had while still working. The most significant obstacle impeding South Africans to retire successfully is the low savings culture in South Africa by households, but also important is the fact that a great percentage of people do not necessarily preserve their retirement savings when they move from one job to the next. These individuals would rather withdraw their retirement benefits and opt to take the money as cash. This figure was estimated to be as high as 93.5\% in 2013 (National Treasury 2014).

The consequences of low retirement savings are twofold. Firstly, the burden on public finance by the government increases. Secondly, the state pensions paid to the elderly are so low, many have to be dependent on family for support, which means many younger people with families are saddled with the weight of supporting the elderly. This in turn lowers the ability of these younger individuals to save and so the cycle just continues (National Treasury 2012). There is also a so-called 'sandwich' generation. These individuals have to support their children as well as their parents and represent approximately $23 \%$ of the population (Old Mutual 2017). For very low income households, however, the state pensioners are sometimes supporting entire households with only the meagre income they receive (Geldenhuys 2010).

Debt plays a major role in low retirement savings. Individuals might have retirement savings, but could still have large amounts of debt that has to be paid off while they are retired. The ideal for successful retirement lies in the notion that debt will be fully paid when a person retires. Unfortunately, some 
individuals do not have a choice other than going into debt and because of this, they feel trapped (Old Mutual 2017).

\section{The clergy and retirement}

A definition provided by Dik and Duffy (2009) states that a calling is a:

transcendent summons, experienced as originating beyond the self, to approach a particular life role in a manner oriented toward demonstrating or deriving a sense of purpose or meaningfulness and that holds other-oriented values and goals as primary sources of motivation. (p. 427)

This ministerial calling also does not focus on personal victories, church size or money, but rather places emphasis on the selfless and spiritual nature of the ministerial career (Christopherson 1994).

The reason for choosing the ministry is a vocational calling and not necessarily focussed on earning a high income, as with other professions. In addition, according to the Word of God, money should be seen as a tool to fulfil God's purpose and not an end in itself. As a result of the teachings of the Bible, clergy are not encouraged to focus too much on money and that could lead to less successful money management (Keehn 2016). As mentioned in a study of Catholic priests in America, ' $[t]$ he priesthood is not a lucrative profession' (Kane \& Jacobs 2015:124), and scripture such as Matthew (6:24), '[y] ou cannot serve both God and Mammon', can further complicate the relationship between serving God and managing money.

Apart from financial factors that could cause anxiety before or during retirement, other specific factors also come into play with the retirement of clergy. Matters such as the transition from the pulpit to the church pew, the possible loss of identity and status, the move out of church-provided housing, downscaling to a smaller property, or the move away from the congregation, can all have an enormous impact on a ministerial retiree (Clark 2003). Another aspect that can become problematic is the concept that being called into the ministry is a vocation and not just a job. Some ministers might feel that they do not want to retire but work for God for as long as they can (Park \& Smith-Bezjian 2009).

In a study conducted by Knapp, Pruett and Hicks (2009), Church of Christ Protestant ministers in Texas were surveyed in relation to their retirement. The study found that the intention of $46.4 \%$ of the sample was to only partially retire, while $28.7 \%$ had no intention to ever retire. That left only $24.9 \%$ who wanted to completely retire. The most common reason for these results was a lack of retirement finances. It seems that the impulse to remain working is not just a South African phenomenon. Some of the Texan respondents indicated that their chosen vocation was a calling and therefore they did not want to retire, but the data in the study suggested that financial need was a driving force behind this decision. A similar study was undertaken in 2012 which selected a stratified sample of a population of all Church of
Christ Protestant minister from across the USA. The results were very similar to those observed in Texas, with $32.7 \%$ indicating that they would fully retire, $38.6 \%$ that they would partially retire and $28.7 \%$ that they had no intention to retire (Knapp \& Pruett 2017). A study by Kane and Jacobs (2015) also found that the most desirable option for Catholic priests in the USA is semi-retirement, where they do not have a large administrative burden but still have the satisfaction of pastoral service and ongoing payment to supplement their retirement savings. However, the expectation in the Catholic Church seems to be that priests are expected to work until they are not physically and/or cognitively able to serve anymore. A priest can scale down on responsibilities, but to retire entirely is seen as selfish and self-indulgent.

Another study (Park \& Smith-Bezjian 2009) focussed on Korean minsters in Southern California and found that more than $85 \%$ of the ministers had not planned for retirement. The possible reasons listed for this attitude towards retirement were the belief that they could work longer than other workers, they had faith that God would provide in the present and during retirement, that financial resources during retirement were not an important issue, as well as a combination of all of these factors.

The majority of the international studies considered indicated that the specific church denominations do not offer retirement plans to their ministers. In most cases, the ministers will have their own retirement savings or their church will start some form of retirement savings for them (Clark 2003; Knapp et al. 2009; Knapp \& Pruett 2017; Park \& Smith-Bezjian 2009). The situation for Dutch Reformed ministers in South Africa looks quite different. All ministers are obligated to be part of a Predikante Pensioenfonds (PPF). Even though the pension fund provides ministers with extensive benefits, it is still communicated to ministers that they should have additional retirement savings in order to retire independently (PPF Nuusbrief 2016).

During the 16th meeting of the General Synod of the Dutch Reformed Church notice was taken of the implications of the fact that a great number of ministers would retire in the next few years (Agenda Algemene Sinode 2015:362).

\section{Research design and method Research approach}

In 2015, all Dutch Reformed ministers in South Africa and Namibia who would reach retirement age within the next 5 years were identified by the General Synod database. This research was conducted under orders from the General Synod to the Research Task Team of the General Synod of the Dutch Reformed Church. A total of 309 ministers were identified to fall within the category. All ministers were requested to complete the questionnaire, which means a census method was used to collect the data, rather than selecting a sample. According to Cooper and Schindler (2006) a census, rather than sampling, would increase accuracy 
when dealing with a relatively small and an easily accessible population. A total of 309 online questionnaires were e-mailed to the ministers through the EvaSys program and 147 useable questionnaires were returned. The response rate was therefore $47.7 \%$. A summary of the results of the project was published in 2016 in the Stellenbosch Theological Journal (Alsemgeest, Schoeman \& Swart 2016). This summary provided an overview of the entire study, which was focussed on the perceptions of near-retirement ministers of their congregation, their personal well-being and their finances. No specific issue was examined in considerable detail, as only descriptive statistics were discussed. It was therefore a broad overview of the study as a whole, while this article focusses on only a small aspect.

\section{Research participants}

As mentioned before, all Dutch Reformed ministers who took part in the study were within 5 years of retirement. All participants were white males, Afrikaans-speaking and between the ages of 59 and 64 years of age. Most of the participants were still in their first marriage $(85.7 \%)$, while $81.9 \%$ indicated that they were serving in full-time ministering posts. The majority of the respondents $(87.4 \%)$ had served in the church for 30 years or longer, which suggests that ministering is a calling rather than a job and that most ministers have only had this one vocation their entire working life.

\section{Measuring instrument}

In order to obtain data, the study employed a quantitative research design by making use of an online questionnaire, and the link to the questionnaire was e-mailed to the respondents. The questionnaire formed part of a larger study that focussed on the congregation and the minister and his retirement. This study will only report on the personal financial aspects of the minister and his retirement. The financial information was tested mainly on a Likert scale of 1 to 5 , where 1 represents completely disagree, while 5 represents completely agree, with three more options in between (disagree, uncertain and agree). The five-point Likert scale questions included questions such as: I have made enough provision (financially) for retirement; I will have enough money available during retirement to cover my basic expenses; I started saving early enough for retirement. Certain questions also requested the respondent to indicate either yes, uncertain or no. An example of these types of questions was: I have made enough financial provision for after retirement.

The questionnaire's reliability was tested through internal consistency, and the Cronbach's alpha test indicated a result of 0.816. According to George and Mallery (2003), this number indicates that reliability is good. Validity was tested by making use of construct validity and the results of the Kaiser-Meyer-Olken (KMO) and Bartlett's test of sphericity to test sample adequacy was used. The sample is adequate if the $\mathrm{KMO}$ value is more than 0.5 and when the Bartlett's test is significant ( $p$-value less than 0.05) (DeCoster 2004). The KMO for this study for all the line items were high (0.896) and the Bartlett's test indicated a statistically significant result of 0.000 - therefore, the validity is high.

Descriptive statistics, as well as calculating means, correlations, coefficients of determination, cross tabulations and regression analysis were used to analyse the data.

\section{Results}

The respondents were asked to answer statements made to them by either answering yes, uncertain or no. Table 1 presents the three general retirement statements.

Whether the respondents perceived themselves to have made enough provision for retirement is a cause for concern. Approximately only 38\% indicated that they had indeed made enough provision, while a relatively small percentage $(16 \%)$ indicated that they had not. Many respondents indicated that they were uncertain about this statement, which is disturbing, as these respondents were 5 years or less away from their retirement age. Almost 39\% of the respondents indicated that they would not have to continue working after retirement, which is almost exactly the same as the percentage of respondents that had saved enough for retirement. Approximately 23\% of the respondents indicated without any hesitation that they would indeed have to continue working in order to survive. This result corresponds with Geldenhuys (2010), who stated that roughly 31\% of South Africans have to continue working after retirement age, because of low or no savings. Also, again, the large section of the respondents that answered uncertain is disquieting. Lastly, the much-contested issue of part-time ministerial posts was brought up and the majority (46.2\%) indicated that they would want to hold a part-time ministerial post after retirement.

Table 2 reveals the results of calculating the bivariate Pearson correlation coefficient between the three statements and establishing whether there were significant relationships. The statement I have made enough provision (financially) for

TABLE 1: General retirement statements.

\begin{tabular}{lccc}
\hline Statements & Yes (\%) & Uncertain (\%) & No (\%) \\
\hline $\begin{array}{l}\text { I have made enough provision } \\
\text { (financially) for retirement. }\end{array}$ & 37.7 & 45.9 & 16.4 \\
$\begin{array}{l}\text { I would have to continue working after } \\
\text { retirement in order to survive. }\end{array}$ & 22.8 & 38.6 & 38.6 \\
$\begin{array}{l}\text { I would want to hold a part-time } \\
\text { ministerial post after retirement. }\end{array}$ & 46.2 & 29.7 & 24.1 \\
\hline
\end{tabular}

TABLE 2: Correlation and statistical significance between the three general retirement statements.

\begin{tabular}{lcc}
\hline Variable & \multicolumn{2}{c}{$\begin{array}{c}\text { I have made enough provision } \\
\text { (financially) for retirement }\end{array}$} \\
\cline { 2 - 3 } & $\begin{array}{c}\text { Pearson correlation } \\
\text { coefficient }\end{array}$ & $\begin{array}{c}\text { Significance } \\
(\boldsymbol{p} \text {-value) }\end{array}$ \\
\hline $\begin{array}{l}\text { I would have to continue working } \\
\text { after retirement in order to survive. }\end{array}$ & $-0.251^{* *}$ & 0.002 \\
$\begin{array}{l}\text { I would want to hold a part-time } \\
\text { ministerial post after retirement. }\end{array}$ & $-0.501 * *$ & 0.000 \\
\hline
\end{tabular}

**Correlation is significant at the 0.01 level (two-tailed). 
retirement was regarded as the core statement and was therefore tested against the other two statements.

The results indicate that there were statistical significant relationships between whether respondents had made enough provision for retirement and whether they would have to or would want to continue working after retirement. The relationship between whether they would have to continue working and whether they would want a part-time ministerial post was also tested and found to be statistically significant (0.000). The correlation analysis indicates the strength and the direction of the relationship and both values is shown to be negative. The relationship between the variables is therefore inverse. That would indicate that if the respondents perceived that they did make enough provision for retirement, then they would not have to continue working in order to survive, and vice versa, which can be considered as a logical result. The relationship is not very strong $(-0.251)$, but there is a significant relationship between the two variables, which is to be expected. The results also indicate that if the respondents did provide enough for retirement, they would not necessarily want to hold a part-time ministerial post after retirement. The strength of the relationship is regarded as moderate (-0.501). Because of this result, it is possible to deduce that the reason for so many respondents to continue in a part-time ministerial post is because of inadequate financial provision for retirement. The negative correlation between whether the respondents have made enough provision, whether they will have to continue working for survival, and whether they will want to hold a part-time ministerial post corresponds with studies conducted in the US that found that the main reason for not fully retiring is financially motivated (Knapp et al. 2009; Knapp \& Pruett 2017).

Respondents also had to answer certain questions by indicating their preference on a scale from 1 to $5(1=$ completely disagree $; 2$ = disagree; $3=$ uncertain $; 4=$ agree and $5=$ completely agree). Table 3 provides evidence from more in-depth retirement questions relating to the respondents' preparedness for retirement. In order to provide a more general perspective, the two options completely disagree and disagree were added together, and the same was done with the response options completely agree and agree. Table 3 provides the percentages of the respondents who disagreed with the 10 statements (opposing), the ones who were uncertain and the percentage who indicated that they agreed with the statements (in favour). The last column provides the mean for each statement, which was calculated on a five-point Likert scale.

The mean indicates the average of all respondents' answers and a number above 3 indicates that the majority of the respondents agree with the statement. From the means, it can be deduced that the statements my debt is not a problem (4.0); I will have enough money available during retirement to cover my basic expenditures (3.87); I have a trustworthy financial advisor that assists me with my retirement planning (3.64); and I am currently doing enough to financially prepare for retirement (3.63) show the highest levels of agreement. All of the statements show a mean of more than 3 (indicating the majority of the respondents agree with the statement), except for the statements I will have an equal standard of living as I do currently and I will have a higher standard of living as I do currently. These two statements, however, represent the ideal retirement situation, namely to retire either with an equal or higher standard of living. The result therefore indicates that the majority of the respondents $(38.3 \%$ disagree and completely disagree) believe that they will not be able to keep up their current standard of living and a very large percentage of respondents (74.5\% disagree and completely disagree) will not be able to live at a higher standard of living. In Table 4 the correlation between the core statement of my financial provision for my retirement is sufficient and the in-depth retirement statements are provided, as well as the statistical significance of the relationships.

The results from Table 4 indicated that all the in-depth retirement statements correlated positively (and significantly) with the respondents' perceptions that their financial provision for retirement would be sufficient. It can therefore be said that an improvement (any move from opposition to in favour) will also increase the respondents' perception that they have made sufficient financial provision for retirement. The coefficient of determination $\left(R^{2}\right)$ measures the strength of the correlation and the percentage indicates the change in the perception of sufficient financial provision that can be accounted for by a change in the perception of the other in-depth retirement statements. It is therefore clear that a

TABLE 3: In-depth retirement statements.

\begin{tabular}{|c|c|c|c|c|}
\hline Statements & In disagreement (\%) & Uncertain (\%) & In agreement (\%) & Mean \\
\hline My financial provision for my retirement is sufficient. & 21.4 & 41.3 & 37.3 & 3.23 \\
\hline $\begin{array}{l}\text { I will have enough money available during retirement to cover my } \\
\text { basic expenditures. }\end{array}$ & 9.6 & 18.5 & 71.9 & 3.87 \\
\hline $\begin{array}{l}\text { I will have enough money available after retirement to cover my } \\
\text { medical expenses during retirement. }\end{array}$ & 15.8 & 45.9 & 38.3 & 3.32 \\
\hline $\begin{array}{l}\text { I will have enough money available during retirement to pay for } \\
\text { long-term care (if needed). }\end{array}$ & 17.2 & 49.3 & 33.5 & 3.24 \\
\hline I am currently doing enough to financially prepare for retirement. & 16.5 & 20.0 & 63.5 & 3.63 \\
\hline I have started early enough for retirement. & 29.9 & 18.8 & 51.3 & 3.26 \\
\hline $\begin{array}{l}\text { I have a trustworthy financial advisor that assists me with my } \\
\text { retirement planning. }\end{array}$ & 21.3 & 11.6 & 67.1 & 3.64 \\
\hline I will have an equal standard of living as I do currently. & 38.3 & 28.1 & 33.6 & 2.88 \\
\hline I will have a higher standard of living as I do currently. & 74.5 & 20.0 & 5.5 & 1.76 \\
\hline My debt is not a problem. & 11.0 & 11.6 & 77.4 & 4.0 \\
\hline
\end{tabular}


TABLE 4: Correlation and statistical significance between the statement $m y$ financial provision for my retirement is sufficient and the in-depth retirement statements.

\begin{tabular}{|c|c|c|c|}
\hline \multirow[t]{2}{*}{ Variable } & \multicolumn{3}{|c|}{$\begin{array}{l}\text { My financial provision for my retirement } \\
\text { is sufficient }\end{array}$} \\
\hline & $\begin{array}{c}\text { Pearson } \\
\text { correlation }(R) \\
\end{array}$ & $R^{2}(\%)$ & $\begin{array}{l}\text { Significance } \\
\text { ( } p \text {-value) }\end{array}$ \\
\hline $\begin{array}{l}\text { I will have enough money available } \\
\text { during retirement to cover my } \\
\text { basic expenditures }\end{array}$ & $0.701 * *$ & 49.1 & 0.000 \\
\hline $\begin{array}{l}\text { I will have enough money available } \\
\text { after retirement to cover my } \\
\text { medical expenses during } \\
\text { retirement }\end{array}$ & $0.640 * *$ & 41.0 & 0.000 \\
\hline $\begin{array}{l}\text { I will have enough money available } \\
\text { during retirement to pay for } \\
\text { long-term care (if needed) }\end{array}$ & $0.665^{* *}$ & 44.2 & 0.000 \\
\hline $\begin{array}{l}\text { I am currently doing enough to } \\
\text { financially prepare for retirement }\end{array}$ & $0.704 * *$ & 49.6 & 0.000 \\
\hline $\begin{array}{l}\text { I have started early enough for } \\
\text { retirement }\end{array}$ & $0.440 * *$ & 19.4 & 0.000 \\
\hline $\begin{array}{l}\text { I have a trustworthy financial } \\
\text { advisor that assists me with my } \\
\text { retirement planning }\end{array}$ & $0.325^{* *}$ & 10.6 & 0.000 \\
\hline $\begin{array}{l}\text { I will have an equal standard of } \\
\text { living as I do currently }\end{array}$ & $0.638 * *$ & 40.7 & 0.000 \\
\hline $\begin{array}{l}\text { I will have a higher standard of } \\
\text { living as I do currently }\end{array}$ & $0.312^{* *}$ & 9.7 & 0.000 \\
\hline My debt is not a problem & $0.324 * *$ & 10.5 & 0.000 \\
\hline
\end{tabular}

***orrelation is significant at the 0.01 level (two-tailed)

TABLE 5: Linear regression between the statement my financial provision for my retirement is sufficient and the in-depth retirement statements.

\begin{tabular}{lcc}
\hline $\begin{array}{l}\text { My financial provision for my retirement is } \\
\text { sufficient }\end{array}$ & $\begin{array}{c}\text { Beta } \\
\text { coefficient }\end{array}$ & $\begin{array}{c}\text { Significance } \\
(p \text {-value) }\end{array}$ \\
\hline $\begin{array}{l}\text { I will have enough money available during } \\
\text { retirement to cover my basic expenditures. }\end{array}$ & $0.293^{* *}$ & 0.000 \\
$\begin{array}{l}\text { I will have enough money available during } \\
\text { retirement to pay for long-term care (if needed). }\end{array}$ & $0.191^{*}$ & 0.013 \\
$\begin{array}{l}\text { I will have an equal standard of living as I do } \\
\text { currently. }\end{array}$ & $0.213^{* *}$ & 0.002 \\
$\begin{array}{l}\text { I am currently doing enough to financially } \\
\text { prepare for retirement. }\end{array}$ & $0.247 * *$ & 0.003
\end{tabular}
prepare for retirement.

*Correlation is significant at the 0.05 level (two-tailed); **Correlation is significant at the 0.01 level (two-tailed).

change in the perception of whether they will be able to cover their basic expenses during retirement, as well as whether they are currently doing enough to prepare financially for retirement, will have the biggest impact on the perception that they have made sufficient financial provision for retirement.

Table 5 provides the results of a linear regression test between the perception of respondents that their financial provision for retirement is sufficient and the other in-depth retirement statements. The table consist of only the statements that were found to be statistically significant with the dependant variable (my financial provision for my retirement is sufficient). The statistical significance column provides the $p$-value and the beta coefficient column offers the extent to which the dependant variable can be influenced by the independent variables.

The results from Table 5 imply that the respondents perceived that they had made sufficient provision for retirement if they would be able to pay their basic expenditures during retirement, if they would be able to pay for long-term care (if needed), if they would have an equal standard of living as currently and lastly: if they thought that they were currently doing enough to financially prepare for retirement.

\section{Discussion}

Only about a third of the study's respondents indicated with certainty that they had made enough provision for retirement. It is thus not surprising that there was a considerable number of respondents who wanted to hold a part-time ministerial post after retirement and who would have to continue working after retirement in order to survive. The problem of unemployment among recently graduated proponents will therefore persist into the near future, which will create a predicament for the Dutch Reformed Church, specifically on how they will manage this problem. The church will have to strike a balance between proponents in need of employment, as well as retired ministers who do not have sufficient retirement savings. Also, another aspect that should receive some attention is the church's ethical role in ensuring that ministers save enough for retirement over their career, so that they do not fill posts designated for younger ministers. In effect, it is also an ethical matter from the retired minister's position. A minister's insufficient provision for retirement and his need to continue employment with the church - even in a reduced capacity - directly impacts on a graduated proponent's ability to gain employment.

A cause for concern is the high number of respondents who indicated uncertainty towards the majority of the statements. The statements made in the questionnaire represented basic retirement information that an individual close to retirement should know. The results from the statement relating to whether they had a trustworthy financial advisor to assist them in their retirement planning are also troubling. A third of the respondents indicated that they did not have, or were uncertain if they had, a trustworthy financial advisor to assist them. It can therefore be expected that they would be unsure about specific issues if they did not have a financial services professional to assist them with some of the more complicated financial issues, calculations and planning. Financial planning as a profession is a highly regulated industry and in order to become qualified, an individual has to have extensive education, training, experience and ethical clearance. It is a highly specialised career, because of the complicated calculations and regulations that form part of it. It is not expected of an individual to have expert knowledge on retirement planning, but rather to realise that there are professionals better equipped to do so. The help of a qualified and trustworthy financial advisor should therefore be non-negotiable in planning for a retirement where clients can retire comfortably and maintain their current lifestyle.

The question also arises whether the uncertainty of respondents towards basic retirement statements was related to their specific vocation and because the relationship between money and God can become blurred. All of the 
respondents were highly educated and should have had basic knowledge about their finances and future planning, but their uncertainty was evident. This result could also indicate a lack of financial literacy or even financial aversion. Financial aversion or financial anxiety (Sochos \& Latchford 2016) are terms that relate to financial ignorance or neglect, which is basically the general avoidance of financial matters.

\section{Conclusion and implication}

The issue of contract ministerial posts being filled by retired ministers instead of proponents in the Dutch Reformed Church has been put under the spotlight in this article. Specific attention has been paid to the perceptions of the large number of near-retirement ministers on their preparedness for retirement. The results indicated that a large percentage of near-retirement ministers will still want to hold a contract post after retirement. The criticism from recently graduated, but unemployed, proponents is that older ministers who have reached retirement age are refusing to step down and retire and instead continue in contract posts. Because of the economic hardships and dwindling church member numbers, contract posts are less expensive to the church and could therefore be preferable for certain congregations of the church. The intention of the near-retirement ministers - of whom there are an unprecedented number set to retire in the next few years - will exacerbate the unemployment problem within the Dutch Reformed Church. This might have an effect on the management of future theological training and also the recruitment of future theological students.

There is a direct relationship between the ministers' motivation to continue working and their lack of financial provision for retirement. As such, the question remains whether their chosen vocation influences this financial ignorance towards retirement planning. There seem to be a specific need for financial training and/or knowledge for theological students, proponents or young ministers. As their vocation has such a distorted relationship with financial management, the training should be specific and focussed in order to provide them with precise information and also emphasise the need for sufficient retirement savings and healthy financial management. An intervention is needed by the church to insist that educational institutions include basic financial literacy and personal financial management in the theological syllabus. If not, the cycle of low retirement savings and unemployment will continue.

The results of this study are exploratory and therefore more in-depth research into the financial practices, behaviours, attitudes and knowledge of theologians is needed to give a more complete picture. Future research could include comparisons between different age groups and religious designations.

The huge uncertainty surrounding retirement issues could be remedied by making theological students, proponents and ministers aware of the need for sound financial management with the assistance of qualified and trustworthy financial advisors in those matters that they are not skilled in doing themselves:

And seeing ignorance is the curse of God,

Knowledge the wing wherewith we fly to heaven

William Shakespeare, Henry VI (1623)

\section{Acknowledgements}

The author acknowledges Prof. Kobus Schoeman (University of the Free State, Faculty of Theology) and Dr Theo Swart (Research Fellow, University of the Free State) for their contribution to the project, in total of which this article only reports on a small part.

\section{Competing interests}

The author declares that she has no financial or personal relationships which may have inappropriately influenced her in writing this article.

\section{References}

Agenda Algemene Sinode, 2015, Agenda vir die 16de vergadering van die Algemene Sinode van die Nederduitse Gereformeerde Kerk, Afrikaanse Hoër Seunskool, Pretoria, Sondag 4 tot Vrydag 9 Oktober 2015, [online], viewed 14 September 2015, from http://www.ngkerkas.co.za/wp-content/uploads/2013/04/Agenda2015, from http://www.n
Algemene-Sinode-2015.pdf

Alsemgeest, L., Schoeman, W.J. \& Swart, T., 2016, 'Imminent retirement: Pastors' experience of their congregation, personal wellbeing and finances', Stellenbosch Theological Journal 2(2), 93-110.

Christopherson, R.W., 1994, 'Calling and career in Christian ministry', Review of Religious Research 35(3), 219-237. https://doi.org/10.2307/3511890

Clark, W.M., 2003, 'Retired ministers and their spouses: Who cares?', Church \& Society 93(5), 73-78.

Cooper, D.R. \& Schindler, P.S., 2006, Business research methods, 9th edn., McGrawHill/Irwin, New York.

DeCoster, J., 2004, Data analysis in SPSS [online], stat-help.com, viewed 14 October 2016, from http://www.stat-help.com/notes.html.

De Klerk, B. \& Van Helden, P., 2011, 'Oorsake van kerkkrimping binne die tradisioneel Afrikaanssprekende gereformeerde kerke in Suid-Afrika', Verbum et Ecclesia 32(1), 10. https://doi.org/10.4102/ve.v32i1.477

Dik, B.J. \& Duffy, R.D., 2009, 'Calling and vocation at work: Definitions and prospects for research and practice', The Counselling Psychologist 37(3), 424-450. https:// doi.org/10.1177/0011000008316430

Facebook, 2012, Kerkbode - "Ek ry wipplank tussen oomblikke van geweldige optimisme en 'n put van ellende...", Facebook. [online], viewed 24 November 2016, from https://www.facebook.com/kerkbode/posts/134508730017635

Geldenhuys, J., 2010, 'Challenges faced by an aging South Africa', in S. Vettori (ed.), Aging populations and changing labour markets: Social and economic impacts of the demographic time bomb, pp. 185-209, Gower, Farnham.

George, D. \& Mallery, P., 2003, SPSS for Windows step by step: A simple guide and reference, 4th edn., Allyn \& Bacon, Boston, MA.

Grobler, R., 2016, 'The poor state of savings in SA', [online], Investec, viewed 12 January 2016, from https://archive.investec.co.za/research-and-insights/business-class/ edition2/entrepreneurial-spirit/The-poor-state-of-savings-in-SA.html

Izekenova, A.K., Kumar, A.B., Abikulova, A.K. \& Izekenova, A.K., 2015, 'Trends in aging of the population and the life expectancy after retirement: A comparative countrybased analysis', Journal of Research in Medical Sciences.: The Official Journal of Isfahan University of Medical Sciences 20(3), 250-252.

Kane, M.N. \& Jacobs, R.J., 2015, “"My bishop told his priests that section 8 housing was an option": Catholic priests, aging, and retirement in the United States', Journal of Religion and Spirituality in Social Work: Social Thought 34, 235-251. https://doi.org/10.1080/15426432.2015.1036153

Keehn, D., 2016, 'A call for financial training to help ministry students manage personal finances', Christian Education Journal [online] 13(2), 6, viewed 09 April 2017, from https://www.aymeducators.org/wp-content/uploads/Dave-Keehns-Paper-forAYME-Training-Students-to-Manage-their-Finances.pdf

Kerkbode, 2012, 'Baie jong leraars is werkloos', 18 Mei, 188(8), 1.

Knapp, J.L. \& Pruett, C.D., 2017, 'Retirement among members of the clergy: Findings from a Protestant fellowship', Journal of Religion, Spirituality \& Aging 29(1), 33-46. https://doi.org/10.1080/15528030.2016.1252824 
Knapp, J.L., Pruett, C.D. \& Hicks, J.L., 2009, 'Clergy and retirement: An exploratory study on housing and financial preparedness', Journal of Religion, Spirituality \& study on housing and financial preparedness, Journal of Religion,
Aging 21(3), 159-171. https://doi.org/10.1080/15528030902803855

National Treasury, 2012, Strengthening retirement savings: An overview of proposals announced in the 2012 Budget [online], viewed 27 June 2016, from http://www. treasury.gov.za/publications/RetirementReform/20120314\%20-\%20 Strengthening $\% 20$ retirement $\% 20$ savings.pdf

National Treasury, 2014, Press release: Statement on the impact of the proposed retirement reforms [online], viewed 21 June 2015, from http://www.treasury.gov. za/comm_media/press/2014/2014070901\%20-\%20Statement $\% 20$ on $\% 2$ the $\% 20$ Impact $\% 20$ of $\% 20$ the $\% 20$ Proposed $\% 20$ Retirement $\% 20$ Reforms.pd

Old Mutual, 2017, 2017 old mutual retirement monitor reveals decline in preservation [online], viewed 14 April 2017, from https://www.oldmutual.co.za/media-centre/ newsdetail/2017/03/08/2017-old-mutual-retirement-monitor-reveals-decline-inpreservation

Palmer, D. \& Krige, J.D., 2013, 'Real age adjusted life expectancy', Journal of economic and Financial Sciences 6(1), 153-166.
Park, G.D. \& Smith-Bezjian, I., 2009, 'Pastors' retirement crisis beyond the shrinking of social security', Journal of Religion, Spirituality \& Aging 21(3), 172-181. https:// doi.org/10.1080/15528030902803905

PPF Nuusbrief, 2016, Predikante Pensioenfonds van die NG Kerk in SA [pdf], Predikante Pensioenfonds van die NG Kerk in SA, Bellville, viewed 13 November 2016, from https://kaapkerk.co.za/wp-content/uploads/2016/06/2016-09 PPFNuusbrief.pdf

Schoeman, W.J., 2014, 'Agter die syfers is gelowiges, gemeentes en die kerk, 'n prakties teologiese refleksie oor lidmaatskap', HTS Teologiese Studies/Theological Studies [online] 70(1), 10. https://doi.org/10.4102/hts.v70i1.2677

Sochos, A. \& Latchford, E., 2016, 'Financial aversion and its link to attachment anxiety', Current Psychology 35(4), 606-614. https://doi.org/10.1007/s12144015-9327-9

World Health Organization (WHO), 2015, Global Health Observatory (GHO) data: Life expectancy [online], viewed 19 April 2017, from http://www.who.int/gho/ mortality_burden_disease/life tables/situation trends/en/ 